\title{
Biogas steam reformer for hydrogen production: Evaluation of the reformer prototype and catalysts
}

\author{
Celso Eduardo Tuna ${ }^{a, *}$, José Luz Silveira ${ }^{a}$, Márcio Evaristo da Silva ${ }^{a}$, \\ Ronney Mancebo Boloy ${ }^{b}$, Lúcia Bolini Braga ${ }^{a}$, Nestor Proenza Pérez ${ }^{b}$ \\ a São Paulo State University, Faculty of Engineering at Guaratinguetá, Department of Energy, Laboratory of \\ Optimization of Energy Systems (LOSE), Brazil \\ ${ }^{\mathrm{b}}$ Federal Center of Technological Education Celso Suckow da Fonseca (CEFET/RJ), Angra dos Reis Campus, Brazil
}

\section{A R T I C L E I N F O}

Article history:

Received 12 September 2017

Received in revised form

10 November 2017

Accepted 3 December 2017

Available online 29 December 2017

Keywords:

Hydrogen production

Biogas steam reforming

Steam reformer

Catalysts

\begin{abstract}
A B S T R A C T
This work aims to investigate a biogas steam reforming prototype performance for hydrogen production by mass spectrometry and gas chromatography analyses of catalysts and products of the reform. It was found that $7.4 \% \mathrm{Ni} / \mathrm{NiAl}_{2} \mathrm{O}_{4} / \gamma-\mathrm{Al}_{2} \mathrm{O}_{3}$ with aluminate layer and $3.1 \% \mathrm{Ru} / \gamma-\mathrm{Al}_{2} \mathrm{O}_{3}$ were effective as catalysts, given that they showed high $\mathrm{CH}_{4}$ conversion, $\mathrm{CO}$ and $\mathrm{H}_{2}$ selectivity, resistance to carbon deposition, and low activity loss. The effect of $\mathrm{CH}_{4}: \mathrm{CO}_{2}$ ratio revealed that both catalysts have the same behavior. An increase in $\mathrm{CO}_{2}$ concentration resulted in a decrease in $\mathrm{H}_{2} / \mathrm{CO}$ ratio from 2.9 to 2.4 for the Ni catalyst at $850{ }^{\circ} \mathrm{C}$, and from 3 to 2.4 for the Ru catalyst at $700{ }^{\circ} \mathrm{C}$. In conclusion, optimal performance has been achieved in a $\mathrm{CH}_{4}: \mathrm{CO}_{2}$ ratio of $1.5: 1 . \mathrm{H}_{2}$ yield was $60 \%$ for both catalysts at their respective operating temperature. Prototype dimensions and catalysts preparation and characterization are also presented.
\end{abstract}

๑ 2017 Hydrogen Energy Publications LLC. Published by Elsevier Ltd. All rights reserved.

\section{Introduction}

Global warming is caused mainly by an excessive fossil fuel use, which has encouraged researchers to develop studies on efficient technologies and renewable sources for generating clean energy in order to replace traditional sources being used nowadays. Hydrogen is a relevant alternative for reducing environmental impacts which are usually caused by greenhouse gas emissions from fossil fuel use, since it is produced sustainably from renewable energy sources [1]. The most representative example of fuel to produce hydrogen is biogas that is typically generated by anaerobic digestion or biomass fermentation [2]. The main components of biogas are methane $\left(\mathrm{CH}_{4}\right) 50-70 \mathrm{vol} \%$ and carbon dioxide $\left(\mathrm{CO}_{2}\right) 25-50 \mathrm{vol}$
$\%$, which also contains $<1$ vol\% $\mathrm{H}_{2}$ and $<3$ vol\% $\mathrm{H}_{2} \mathrm{~S}$, as well as traces of $\mathrm{NH}_{3}$ [3]. Catalytic steam reforming is the most common process to obtain hydrogen, which is usually chosen due to its high efficiency. Moreover, its simplicity and low implementation costs should be compared to other technologies, such as partial oxidation reforming, auto-thermal reforming, dry reforming, and dry oxidation reforming [4]. This technology has been widely applied in chemical industries for large scale $\mathrm{H}_{2}$ production, which is accountable for $50 \%$ of hydrogen generated worldwide by using natural gas as main hydrocarbon source [5]. It is a well-known process which has been described by several authors, e.g. Steinberg [6] and Poirier [7] who reported hydrocarbon reactions, like those of methane, naphtha and ethanol with water (pre-vaporized by a steam

\footnotetext{
* Corresponding author.

E-mail addresses: celso.tuna@feg.unesp.br (C.E. Tuna), joseluz@feg.unesp.br (J.L. Silveira), evaristosm@yahoo.com.br (M.E. da Silva), ronney.boloy@cefe-rj.br (R.M. Boloy), luciabbraga@gmail.com (L.B. Braga), nestor.perez@cefet-rj.br (N.P. Pérez). 


\section{Nomenclature \\ $\Delta \mathrm{h}_{\mathrm{f}}^{0} \quad$ Enthalpy of formation $[\mathrm{kJ} / \mathrm{kmol}]$ \\ HTS High Temperature Shift \\ LTS Low Temperature Shift \\ MCFC Molten Carbonate Fuel Cell \\ RWGS Reverse Water Gas Shift \\ SOFC Solid Oxide Fuel Cell \\ SRB Steam reform of Biogas \\ TCD Thermal conductivity detector \\ TPO Temperature programmed oxidation \\ TPR Temperature programmed reduction \\ WGS Water Gas Shift}

generator). The reactions that occur in this process primarily produce $\mathrm{H}_{2}, \mathrm{CO}_{2}$, $\mathrm{CO}$ and $\mathrm{CH}_{4}$, but there is no set quantity for these compounds whose concentration depend on several factors, such as reagents concentration, temperature and pressure of the reformer, as well as the physical and chemical characteristics of the chosen catalyst.

Steam reform of biogas (SRB), according to Bollini et al. [1], consists essentially in methane steam reforming and methane dry reforming as the following reactions:

$$
\mathrm{CH}_{4}+\mathrm{H}_{2} \mathrm{O}_{\text {(STEAM) }} \leftrightarrow \mathrm{CO}+3 \mathrm{H}_{2} \text { (methane steam reformer) }
$$$$
\Delta h_{f}{ }^{0}=206 \mathrm{~kJ} / \mathrm{mol}
$$

$\mathrm{CH}_{4}+\mathrm{CO}_{2} \leftrightarrow 2 \mathrm{CO}+2 \mathrm{H}_{2}$ (methane dry reformer)

$$
\left(\Delta h_{f}^{0}=247 \mathrm{~kJ} / \mathrm{mol}\right)
$$

Reaction (1) is the overall reaction that occurs in the steam reforming process and occurs at temperatures between 650 and $850^{\circ} \mathrm{C}$, thus obtaining $\mathrm{H}_{2}$ yields of $60-70 \%$, and the $\mathrm{H}_{2} / \mathrm{CO}$ ratio is generally three, i.e. the most appropriate ratio for $\mathrm{H}_{2}$ production [4]. Reaction (2) depicts methane dry reforming, which generally occurs at temperatures ranging between 700 and $900{ }^{\circ} \mathrm{C}$ by using a $\mathrm{CH}_{4} / \mathrm{CO}_{2}$ molar ratio of $1-1.5$, with $\mathrm{H}_{2}$ yields of around 50\%. This reaction is more suitable for Fischer-Tropsch synthesis of biogas to produce liquid hydrocarbons and oxygenated derivatives, thus yielding $\mathrm{H}_{2} / \mathrm{CO}$ ratio close to 1 . Both reactions are highly endothermic and are favored by low pressures and high temperatures.

In addition to these main reforming reactions, other reactions can occur simultaneously that modify the equilibrium conversion of $\mathrm{CO}_{2}$ and $\mathrm{CH}_{4}$, which are going to be presented as follows [4]:

$$
\begin{aligned}
& \mathrm{CO}+\mathrm{H}_{2} \mathrm{O}_{(\text {STEAM })} \leftrightarrow \mathrm{CO}_{2}+\mathrm{H}_{2} \quad\left(\Delta h_{f}{ }^{0}=-41.1 \mathrm{~kJ} / \mathrm{mol}\right) \\
& 2 \mathrm{CO} \leftrightarrow \mathrm{CO}_{2}+\mathrm{C}_{(\text {SOLID })} \rightarrow\left(\Delta h_{f}^{0}=-172.46 \mathrm{~kJ} / \mathrm{mol}\right) \\
& \mathrm{CH}_{4} \leftrightarrow \mathrm{C}_{(\text {SOLID })}+2 \mathrm{H}_{2} \rightarrow\left(\Delta h_{f}^{0}=75.6 \mathrm{~kJ} / \mathrm{mol}\right)
\end{aligned}
$$

Reaction (3) corresponds to the Water-Gas Shift Reaction (WGS), whose catalysts and reaction temperatures can be found in Table 1. The process can operate at high (HTS) or low (LTS) temperatures for eliminating CO produced in the
Table 1 - Catalysts and temperatures in the shift reactor [8].

Catalyst based on $\mathrm{Cu} / \mathrm{Fe} / \mathrm{Cr} \rightarrow$

Reactions HTS $\left(250-450^{\circ} \mathrm{C}\right)$

Catalyst based on $\mathrm{Cu} / \mathrm{Zn} \rightarrow$

Reactions LTS $\left(150-250^{\circ} \mathrm{C}\right)$

reforming reactor, which enables the production of an additional amount of $\mathrm{H}_{2}$ [4]. Unlike other reactions, it is exothermic and may occur at lower temperatures.

Bouduard's reaction (Eq. (4)) describes carbon formation by carbon monoxide decomposition. This reaction is very important for the process, since it is responsible for solid carbon deposition in catalysts. Methane dehydrogenation, shown in reaction (Eq. (5)), is one of the reactions that produce hydrogen while the reforming process is taking place, which also occurs in the reformer.

In biogas steam reforming processes, numerous supported catalysts have been tested. Catalysts are substances that are used in chemical reactions with the aim of accelerating them without being depleted. The materials which are mostly used as catalysts are palladium, ruthenium, iridium, tungsten, manganese, iron, silver, tantalum, titanium, vanadium, nickel, copper, and platinum [9]. In Table 2, examples of commonly used catalysts and their operating temperatures are listed, as well as the preparation technique being used. In the reforming process, most catalytic components are $\mathrm{Ni}$ based, as $\mathrm{Ni} / \mathrm{Al}_{2} \mathrm{O}_{3}$ [10]. This fact is due to the low cost of the component and its satisfactory efficiency.

Many supported catalysts in steam reforming have been tested, specially Ni-based catalysts, by some researchers, such as Kolbitsch et al. [12], Goula et al. [17], Urasaki et al. [18], Fonseca et al. [19] and Sabirova et al. [20]. However, one of the main problems of Ni-based catalysts is that they are subject to several types of deactivations, e.g. sintering, oxidation, carbon deposition and sulfur poisoning [15]. Among them, the most serious one is the formation of carbon deposits on catalysts which, consequently, lead to a blockage of catalyst pores by the deposited carbon, a separation of the catalyst by its support and lock on gas flow, due to an increase in pressure caused by pore blockage [21]. It occurs when the decomposition reaction of carbon monoxide, together with the decomposition reaction of methane (Reaction 5) are faster than the carbon removal rate is [4].

One common way to avoid these problems is to add suitable promoters that increase the stability of Ni-based catalysts, or to introduce a second metal component to form a

Table 2 - Catalysts for the biogas steam reforming system.

\begin{tabular}{llc} 
Catalyst & Preparation technique & $\begin{array}{c}\text { Temp. } \\
\left({ }^{\circ} \mathrm{C}\right)\end{array}$ \\
\hline $15 \% \mathrm{Ni} / 10 \% \mathrm{ZrO}_{2} / \mathrm{Al}_{2} \mathrm{O}_{3}[3]$ & Co-impregnation & $500-700$ \\
$5 \% \mathrm{Ni} / 5 \% \mathrm{La}_{2} \mathrm{O}_{3} / \mathrm{Al}_{2} \mathrm{O}_{3}[11]$ & Impregnation/Calcination & $550-800$ \\
$11,5 \% \mathrm{Ni}_{2} \mathrm{Al}_{2} \mathrm{O}_{3}[8]$ & Reduction & $650-850$ \\
$\mathrm{CaO} / \mathrm{Al}_{2} \mathrm{O}_{3}[12]$ & Impregnation & $650-860$ \\
$5 \% \mathrm{Pt} / \mathrm{\gamma Al}_{2} \mathrm{O}_{3}[13]$ & Impregnation & $500-900$ \\
$\mathrm{Ni} / \mathrm{Mg} / \mathrm{Al}_{2} \mathrm{O}_{4}[14]$ & Impregnation & $650-800$ \\
$\mathrm{Ni} \mathrm{Al}_{3} \mathrm{Al}[15]$ & Impregnation & $600-800$ \\
$\mathrm{Ni}-\mathrm{Ti}$ xerogel $[16]$ & Sol-gel/Calcination & $200-700$ \\
\hline
\end{tabular}


bimetallic catalyst system so as to inhibit carbon formation [22]. Some studies have used these techniques, some of which were reported by $\mathrm{Xu}$ et al. [22] by using $\mathrm{Ni}-\mathrm{Co} / \mathrm{La}_{2} \mathrm{O}_{3}-\mathrm{Al}_{2} \mathrm{O}_{3}$ catalysts. Therdthianwong et al. [3] and Angeli et al. [23] report the use of $\mathrm{ZrO}_{2}$ as $\mathrm{Ni} / \gamma-\mathrm{Al}_{2} \mathrm{O}_{3}$ promoter. The use of other oxides, such as $\mathrm{K}, \mathrm{Sn}, \mathrm{Mn}$ and $\mathrm{Ca}$, has been reported by Luna and Iriarte [24]. The use of noble metals, such as Rh, Ru, Pt, and Pd, has also been studied by many researchers [25-29].

However, it is evident that these types of bimetallic or pure catalysts are of difficult commercialization due to their complex transportation and elevated costs. Thus, intensive research efforts are currently being made in order to improve the performance and lifetime of alumina-supported nickel catalysts [30].

Thereby, the principal aim of the present work is to investigate the performance of $\mathrm{NiAl}_{2} \mathrm{O}_{4} / \gamma-\mathrm{Al}_{2} \mathrm{O}_{3}$ catalyst in order to compare its catalytic activity under $\mathrm{CH}_{4} / \mathrm{CO}_{2}$ reforming conditions and evaluate its resistance to carbon formation with a $\mathrm{Ru} / \gamma-\mathrm{Al}_{2} \mathrm{O}_{3}$ catalyst. The effect of operating conditions $\left(\mathrm{CH}_{4} / \mathrm{CO}_{2}\right.$ molar feed gas ratio of $1.5: 1$ and 1:1) and temperature $\left(650-850{ }^{\circ} \mathrm{C}\right)$ on $\mathrm{CH}_{4}, \mathrm{CO}_{2}$ conversions and $\mathrm{H}_{2} / \mathrm{CO}$ ratio for the two catalysts under study by employing an experimental pilot unit.

\section{Experimental procedure}

\section{Catalyst preparation}

Aluminum oxide $\left(\gamma-\mathrm{Al}_{2} \mathrm{O}_{3}\right)$ was used as supporting material for $\mathrm{Ni}$ and $\mathrm{Ru}$ based catalysts. The support $\gamma-\mathrm{Al}_{2} \mathrm{O}_{3}$ was prepared by a precipitation process with solutions of aluminum nitrate $\mathrm{Al}\left(\mathrm{NO}_{3}\right)_{3} \cdot 9 \mathrm{H}_{2} \mathrm{O} ;(0.5 \mathrm{~mol} / \mathrm{l})$ and ammonium hydroxide $\mathrm{NH}_{4} \mathrm{OH}$ $(6 \mathrm{~mol} / \mathrm{l})$. The process consists in adding an aluminum nitrate solution by using a peristaltic pump with constant flow into the ammonium hydroxide solution under constant stirring and maintaining $\mathrm{pH} \geq 10$. After precipitation, the system was left at rest for aging during $16 \mathrm{~h}$ at $298 \mathrm{~K}$, and then it was filtered and washed with distilled water at $333 \mathrm{~K}$ to remove the precipitating agent until it presented neutral $\mathrm{pH}$. The obtained aluminum hydroxide was dried in a vacuum oven during $16 \mathrm{~h}$ at a temperature of $343 \mathrm{~K}$. After the material was cooled in a desiccator, it was crushed and then burned in a muffle furnace at $773 \mathrm{~K}$ during $3 \mathrm{~h}$ at a heating rate of $10^{\circ} \mathrm{C} / \mathrm{min}$.

Conventional incipient wetness impregnation was used to prepare the $\mathrm{Ni} / \gamma-\mathrm{Al}_{2} \mathrm{O}_{3}$ and $\mathrm{Ru} / \gamma-\mathrm{Al}_{2} \mathrm{O}_{3}$ catalysts. The impregnation solutions were prepared by dissolving nickel nitrate hexahydrate $\mathrm{Ni}\left(\mathrm{NO}_{3}\right)_{2} \cdot 6 \mathrm{H}_{2} \mathrm{O}$ and Ruthenium chloride trihydrate $\mathrm{RuCl}_{3} \cdot 3 \mathrm{H}_{2} \mathrm{O}$ with the required concentration values in order to obtain final catalysts with Nickel content of $7.5 \%$ and Ruthenium content of $3.4 \%$, respectively, which were then impregnated onto an $\mathrm{Al}_{2} \mathrm{O}_{3}$ support. It was employed distilled water as liquid in an automatic pipette of $10 \mathrm{ml}$. After impregnation, the catalysts were dried in a vacuum oven for $16 \mathrm{~h}$ at $343 \mathrm{~K}$. Then, they were calcined at temperatures from $300 \mathrm{~K}$ to $773 \mathrm{~K}$ at $10^{\circ} \mathrm{C} / \mathrm{min}$ heating rate and the same temperature was kept for $1 \mathrm{~h}$. Ni/ $\gamma-\mathrm{Al}_{2} \mathrm{O}_{3}$ was calcined again in air at $850{ }^{\circ} \mathrm{C}$ for $10 \mathrm{~h}$ in order to enhance $\mathrm{NiO} / \mathrm{Al}_{2} \mathrm{O}_{3}$ interaction to form $\mathrm{NiAl}_{2} \mathrm{O}_{4}$. Finally, the catalysts were crushed and sieved into granules with particle sizes ranging between 0.3 and
$0.5 \mathrm{~mm}$ before being loaded onto the reactor for experimental testing.

\section{Catalyst characterization}

Temperature Programmed Reduction (TPR) experiments were carried out in a quartz fixed bed reactor by using a CHEMBET 3000 analyzer. $0.15 \mathrm{~g}$ of calcined catalysts was heated from $27^{\circ} \mathrm{C}$ to $200{ }^{\circ} \mathrm{C}$ at a heating rate of $10^{\circ} \mathrm{C} / \mathrm{min}$ and flow rate of $50 \mathrm{ml} / \mathrm{min}$ for $1 \mathrm{~h}$. After being dried, the material was cooled to $110{ }^{\circ} \mathrm{C}$. Once a certain temperature is reached, a reduction mixture was formed by $5 \% \mathrm{H}_{2} / \mathrm{N}_{2}$ at the same flow rate $(50 \mathrm{ml} /$ $\mathrm{min})$ to replace the carrier gas. After stabilization, the temperature was raised to $1000{ }^{\circ} \mathrm{C}$ at a rate of $10^{\circ} \mathrm{C} / \mathrm{min} . \mathrm{H}_{2}$ consumption during TPR was monitored continuously by a thermal conductivity detector (TCD).

To determine the amount of carbon deposited on the catalysts, they were submitted to Temperature Programmed Oxidation (TPO) and Temperature Programmed Reduction (TPR) in the presence of methane and oxygen, respectively, which were then subjected to thermogravimetric and mass spectrometry analyses. These analyses aim to determine reduction and oxidation temperatures of materials that were identified by changes in mass and resulting gases. About $50 \mathrm{mg}$ of catalysts was placed in a crucible under gaseous mixture flow comprising $10 \% \mathrm{CH}_{4}$ and $10 \% \mathrm{CO}_{2}$ with argon as being the carrier gas (Ar). In the case of TPR, a total flow of $80 \mathrm{ml} / \mathrm{min}$ is kept. For TPO, it was used $20 \%$ of $\mathrm{O}_{2}$. In both cases, $2 \%$ of $\mathrm{He}$ was used as reference for calculating the concentration of gases it had produced. The materials were subjected to heating from 25 to $1000^{\circ} \mathrm{C}$ at a rate of $5^{\circ} \mathrm{C} / \mathrm{min}$.

\section{Catalyst activity experiments}

The catalysts that had already been analyzed in the previous section were evaluated in an experimental pilot unit (Fig. 1) which was designed and built in the Laboratory of Optimization of Energy Systems (LOSE). The cycle comprises a tank for distilled water (1), a metering pump (2), a vaporizer (3), a biogas injection system (4), a biogas/steam mixing chamber (5), a reformer (6), a cooling system (7), a water-gas shift reactor (8), a cooling system (9), a buffer tank with a manometer for checking the synthesis gas pressure (10), an electronic purificator (11), a coalescing filter (12), outlet for the condensate (13) and another for the synthesis gas (14).

The catalyst was evaluated at atmospheric pressure in a fixed-bed reactor (Reformer and water-gas shift reactor) which was connected after the biogas/steam mixing chamber was placed, whose dimensions can be seen in Fig. 2. The biogas/steam mixture enters into the reformer at the bottom of the reactor through $0.003 \mathrm{~m}$ holes distributed along the support plate of the reactor, which is $0.01 \mathrm{~m}$ thick. Thermal insulation was performed with a refractory and ceramic fiber. With the purpose of achieving better temperature control and contact time between the catalyst and the achievable mixture, the reformer must have the following characteristics: $0.114 \mathrm{~m}$ of diameter between the isolation wall and the reformer external wall and $0.0762 \mathrm{~m}$ of internal bed and a bottomperforated plate with $0.003 \mathrm{~m}$ holes, totaling approximately $30 \%$ of free area. It was installed a thermocouple for 

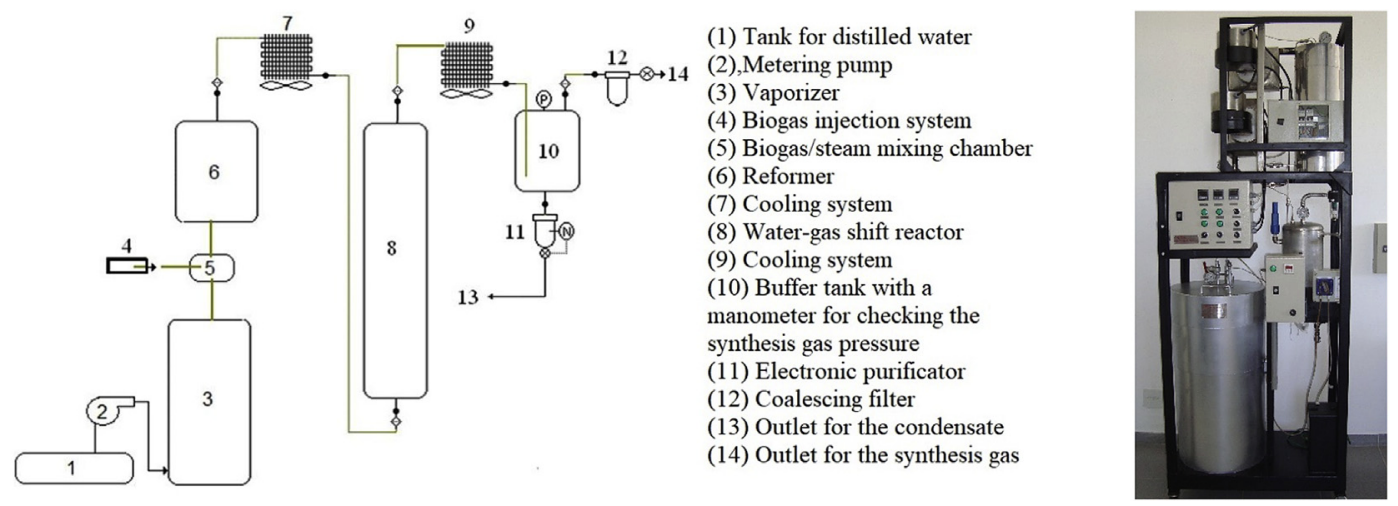

Fig. 1 - Schematic and prototype of the biogas steam reforming system.

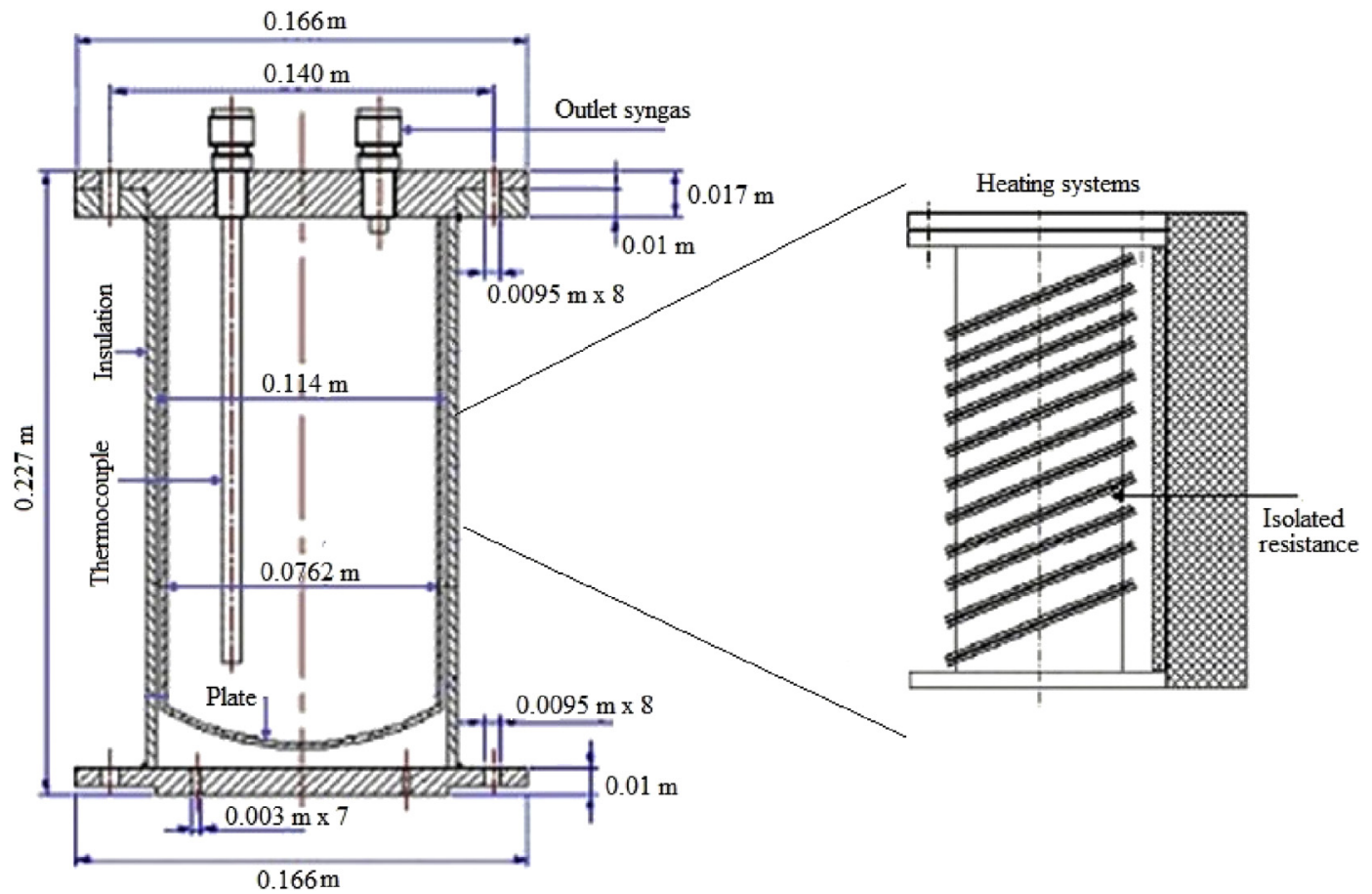

Fig. 2 - Reformer schematic.

temperature control and an outlet for the syngas to be released from reforming reactions. A schematic comprising the heating system, thermal insulation composed of refractory products and isolated resistance with beads can be seen in Fig. 2.

The shift reactor, presented in Fig. 3, consists of a thermally insulated cylinder, with a built-in bed and a perforated plate to provide support for the catalytic converters to interact with the synthesis gas from the reforming reactor. The synthesis gas of the reformer, after the cooling system, enters into the shift reactor at the bottom of the reactor through a connecting tube with $0.004 \mathrm{~m}$ diameter inserted in the support plate which is $0.01 \mathrm{~m}$ thick. The internal diameter is similar to that the reforming reactor, except for its length being twice as much as that of the reformer to promote the conversion of part of the $\mathrm{CO}$ into $\mathrm{CO}_{2}$ and the production of additional $\mathrm{H}_{2}$. The cooling system of the produced synthesis gas, which was installed after the reform and Shift reactions can be also seen in Fig. 3, which is composed of a cooling system through conduction and convection (9), a buffer tank with a manometer to check the pressure of the synthesis gas (10), an electronic purificator (maximum pressure of 175 psi) for condensate removal (11), coalescent filter to remove the remaining moisture in the synthesis gas (12) and two outputs, (13) and (14), respectively, the condensate output and the synthesis gas output with low moisture content.

In the reform, it was used a total flow rate of $2.5 \mathrm{l} / \mathrm{min}$ which is controlled by mass flow meters, being $20 \%$ biogas mixture and balance in Ar with $1 \% \mathrm{He}$. The fixed bed reactor was loaded with $1200 \mathrm{~g}$ of catalyst, and heated up to reduction temperature, corresponding to each type of catalyst (heating rate of $10{ }^{\circ} \mathrm{C} / \mathrm{min}$ ). Two compositions were used for biogas, the first one containing $60 \% \mathrm{CH}_{4}$ and $40 \% \mathrm{CO}_{2}$, which means a molar fraction ratio of $\mathrm{CH}_{4}: \mathrm{CO}_{2}=1.5: 1$ and the second one with $50 \%$ $\mathrm{CH}_{4}$ and $50 \% \mathrm{CO}_{2}\left(\mathrm{CH}_{4}: \mathrm{CO}_{2}=1: 1\right)$. For the steam concentration, it was used a constant value of one and a half times greater 

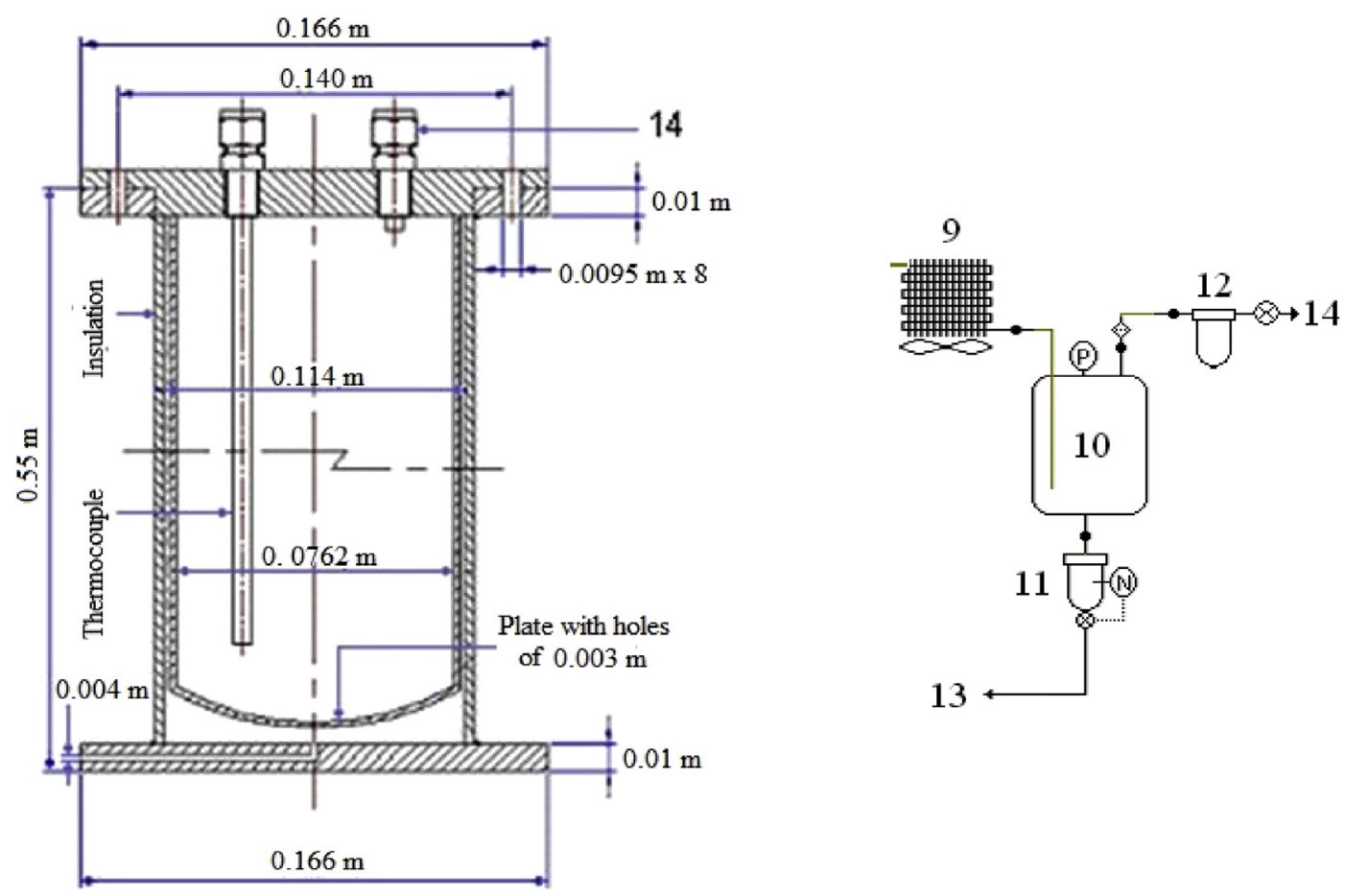

Fig. 3 - Schematic drawing of the Shift reformer and cooling system.

than the concentration of biogas (Steam/Biogas $=1.5)$. The biogas mixture was composed of $20 \%$ of the compound itself $\left(\mathrm{CH}_{4}: \mathrm{CO}_{2}=1.5: 1\right.$ or $\left.1: 1\right), 79 \%$ argon and $1 \%$ helium, which is necessary for calculating the concentration of gases. The tests lasted thirty minutes for each catalyst, or until a considerable deactivation of the catalyst was identified. Once tested, the catalysts were reactivated by using $\mathrm{O}_{2}$ flow, in order for the material to be reoxidized and the carbon deposits to be removed. Reforming biogas tests were performed at different temperatures $\left(650-850{ }^{\circ} \mathrm{C}\right)$. The concentrations of gaseous products $\mathrm{H}_{2}, \mathrm{CO}_{2}, \mathrm{~N}_{2}, \mathrm{CH}_{4}$ and $\mathrm{CO}$ in the product gas were analyzed by mass spectrometry and gas chromatography.

\section{Results and discussion}

\section{Characterization of catalysts by the TPR and TPO tests}

$\mathrm{NiAl}_{2} \mathrm{O}_{4} / \gamma-\mathrm{Al}_{2} \mathrm{O}_{3}$ catalyst

Fig. 4 shows the temperature programmed reduction curve for the fresh Ni-base catalyst. The TPR curve analysis suggests that the reduction of bulk nickel oxide or NiO species, either with or without a weak interaction with the $\mathrm{Al}_{2} \mathrm{O}_{3}$ support, was negligible. It indicates that if these species were present in the catalyst, they would be in a very small quantity because this process occurs at relatively low temperatures (lower than $550^{\circ} \mathrm{C}$ ) [31] and no peak was observed in that range. The first peak was observed at a temperature of $558{ }^{\circ} \mathrm{C}$ and it can attributed to a small quantity reduction of non-stoichiometric nickel aluminate species (NiAlxOy) present in the surface, which is consistent with previous reports $[17,32]$. The major peak presented a narrow shaped peak at $780^{\circ} \mathrm{C}$, which can be assigned to the presence of the $\mathrm{NiAl}_{2} \mathrm{O}_{4}$ phase [22] being

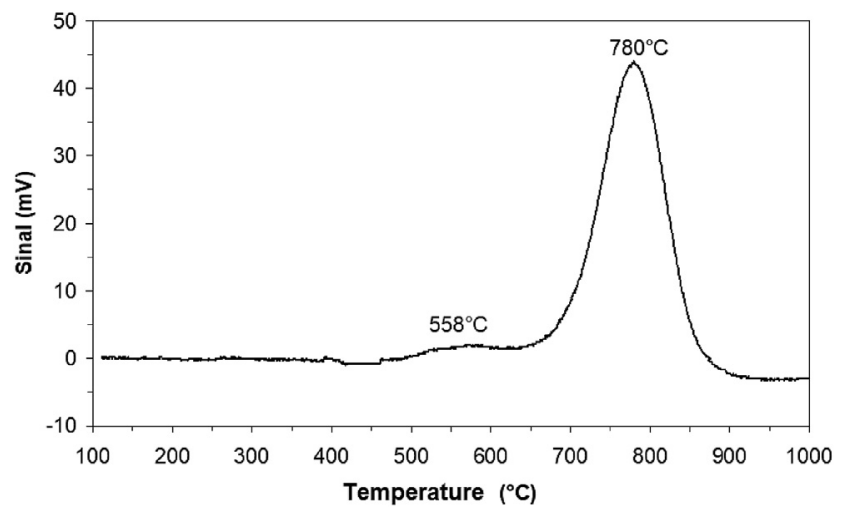

Fig. 4 - Ni catalyst (TPR) with $5 \% \mathrm{H}_{2} / \mathrm{N}_{2}, 10{ }^{\circ} \mathrm{C} / \mathrm{min}$ and $50 \mathrm{ml} / \mathrm{min}$.

formed by the diffusion of nickel ions in the support. These peaks confirm the existence of an interfacial $\mathrm{NiAl}_{2} \mathrm{O}_{4}$ layer on the catalyst that could interrupt the ground of $\mathrm{Ni}$ metallic particles, thus stabilizing the formation of small size $\mathrm{Ni}$ metallic crystallites under reduction conditions. This exerts a favorable effect on performance, stability and lifetime of the catalyst in the biogas steam reforming reaction, given that nickel aluminate interacts more strongly with nickel metallic and alumina in comparison with their interaction [33].

Catalyst reducibility has been studied by several researchers. Zielinski [34] investigated the influence of different wt\% of $\mathrm{Ni}(2-20 \%)$ on a $\mathrm{Ni} / \mathrm{Al}_{2} \mathrm{O}_{3}$ catalyst obtained by the impregnation method followed by calcination at $400^{\circ} \mathrm{C}$. For all samples, all reduction peaks were observed at a range of $400-500{ }^{\circ} \mathrm{C}$, which was attributed to $\mathrm{NiAl}_{2} \mathrm{O}_{4}$. In another study reported by Zhang et al. [35], the alumina support was 
calcined at $600^{\circ} \mathrm{C}$ after impregnation with nickel. For a sample with $2 \mathrm{wt} \% \mathrm{Ni}$, only one peak at $527^{\circ} \mathrm{C}$ was observed, which was assigned to the reduction of nickel aluminates surface. Three significant reduction peaks were detected in Salhi et al. [30] and Zhou et al. [36] studies. In these cases, the reported TPR that corresponds to the reduction of $\mathrm{NiAl}_{2} \mathrm{O}_{4}$ were $800{ }^{\circ} \mathrm{C}$ and $830^{\circ} \mathrm{C}$, respectively. These results are different from the one reported in this study, probably in the first two cases, by the differences in calcination temperature being used in these works. As regards the study of Salhi et al. [30], the difference can be influenced by the catalyst preparation method, where the sol-gel and incipient wetness impregnation methods were used in each case. Finally, the used bimetallic catalyst $\mathrm{Ni} / \gamma$ $\mathrm{Al}_{2} \mathrm{O}_{3} /$ alloy in the study reported by Zhou et al. [36] may be the cause of such differences.

Fig. 5 shows the TPR in the presence of $10 \% \mathrm{CH}_{4}$ and $10 \%$ $\mathrm{CO}_{2}$, respectively, followed by thermogravimetric and mass spectrometry analyses. It is observed a small mass loss occurring from $653^{\circ} \mathrm{C}$, which is probably due to a small percentage of existing aluminate species in the catalyst, but the most significant weight loss occurred at $750{ }^{\circ} \mathrm{C}$ due to a complete reduction of $\mathrm{NiAl}_{2} \mathrm{O}_{4}$ coinciding with the $\mathrm{H}_{2}$-TPR test. It demonstrates that the most significant production of $\mathrm{CO}$ and $\mathrm{H}_{2}$ (characteristic of the dry reforming) occurs from $800{ }^{\circ} \mathrm{C}$. This result allows affirming that higher or equal temperatures are required than those of the steam reforming reactions in a fixed bed reactor. At $871{ }^{\circ} \mathrm{C}$, there was an increase in mass, which is a characteristic phenomenon of carbon deposit. By considering mass reduction, it can be estimated that the material contains approximately $7.4 \% \mathrm{Ni}$, thus finally confirming the catalyst composition as being $7.4 \% \mathrm{Ni} / \mathrm{NiAl}_{2} \mathrm{O}_{4} / \gamma$ $\mathrm{Al}_{2} \mathrm{O}_{3}$. The catalyst appeared selective for the production of $\mathrm{CO}$ and $\mathrm{H}_{2}$, however, due to a reduced amount of the material used in the thermobalance tests, these results must be confirmed by the reforming tests in the pilot experimental installation.

The Temperature Programmed Oxidation (TPO) test (not shown here) showed an increase in catalyst mass due to its reoxidation. Moreover, the production of $\mathrm{CO}$ or $\mathrm{CO}_{2}$, due to the reaction of oxygen with the deposited carbon, has not been possible to be registered by mass spectrometry. Therefore, the absence of $\mathrm{O}_{2}$ consumption signal in the deactivated catalyst

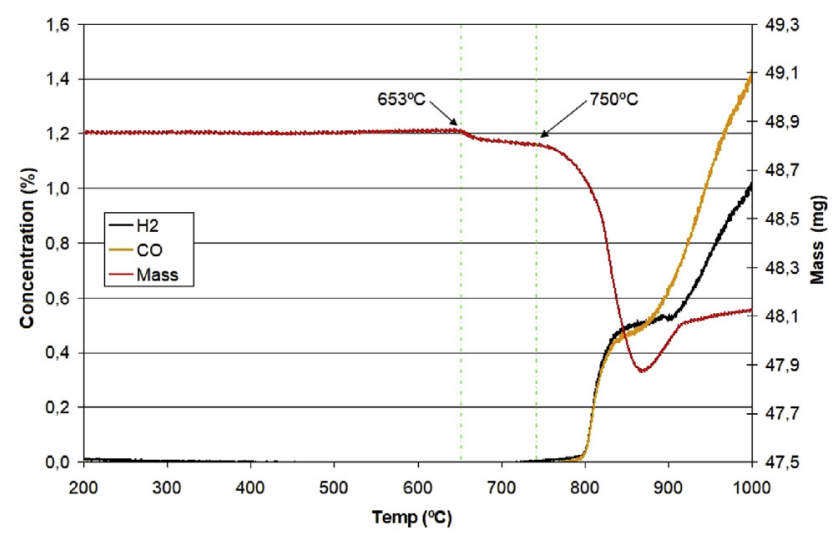

Fig. 5 - Ni catalyst (TPR) with $10 \% \mathrm{CH}_{4}$ and $10 \% \mathrm{CO}_{2}, 5{ }^{\circ} \mathrm{C} /$ $\mathrm{min}$, and $80 \mathrm{ml} / \mathrm{min}$. is an indicator of low concentration of deposited carbon, thence indicating that there may be serious problems of carbon coking during the steam reforming test.

$\mathrm{Ru} / \gamma-\mathrm{Al}_{2} \mathrm{O}_{3}$ catalyst

The TPR profiles with $5 \% \mathrm{H}_{2} / \mathrm{N}_{2}$ of $\mathrm{Ru} / \gamma-\mathrm{Al}_{2} \mathrm{O}_{3}$ catalyst are shown in Fig. 6. The identification of different species of ruthenium oxides, shown in Fig. $6 a$ and $b$, is extremely difficult, since this metal evolves the $\mathrm{RuCl}_{3}$ into different suboxides and, during TPR, other unknown species of ruthenium may be formed on the support surface [37]. TPR curves of $\mathrm{Ru} / \gamma$ $\mathrm{Al}_{2} \mathrm{O}_{3}$ catalyst shows a higher peak at $198{ }^{\circ} \mathrm{C}$, which it is attributed to $\mathrm{RuO}_{2}$ reduction in accordance with the results reported in literature. Koopman et al. [38] attributed a peak between 177 and $205^{\circ} \mathrm{C}$ to the reduction of $\mathrm{RuO}_{2}$ on silica, while Mazzieri et al. [39] found a maximum peak at $197^{\circ} \mathrm{C}$ and a low one at about $156^{\circ} \mathrm{C}$, which are attributed to the reduction of ruthenium oxide and ruthenium oxychloride, respectively. The different behavior of TPR profile shown in this study in comparison with others [38-40], (where only one or two peaks were observed), can be attributed to the catalyst preparation methods, as well as the calcination and reduction process used in each case $[3,17,31,41]$.

Between 300 and $700{ }^{\circ} \mathrm{C}$, the analysis of Fig. 6 makes it clear that the reductions are more intense in the pre-reduced material at $400{ }^{\circ} \mathrm{C}$. This treatment favors the release of chlorine as ruthenium chloride, which is a very stable species that hinders the reduction $\mathrm{Ru}$ to state zero. However, RTP evidences a lower temperature reduction with the Ru catalyst if compared to that of Ni catalyst, which shows that it can favor the reaction with biogas since the element assumes metallic characteristics under less severe reaction conditions (lower temperature).

Fig. 7 shows the reducibility of $\mathrm{Ru}$ in the presence of $10 \%$ $\mathrm{CH}_{4}$ and $10 \% \mathrm{CO}_{2}$, respectively, followed by thermogravimetric and mass spectrometry analyses. A significant and rapid loss of mass occurred the moment a temperature of $470{ }^{\circ} \mathrm{C}$ was reached, due to a reduction of ruthenium oxide, whose results are consistent with those obtained during the reduction with $\mathrm{H}_{2}$. It is noticed that the production of $\mathrm{CO}$ and $\mathrm{H}_{2}$ (characteristic of the dry reforming) occurs at $470^{\circ} \mathrm{C}$, which is a very low value obtained with the Ni catalyst $\left(750^{\circ} \mathrm{C}\right)$. Then, with this catalyst, it must be working at or above temperatures of $470^{\circ} \mathrm{C}$ for steam reforming reactions occurring in a fixed bed reactor. By considering mass reduction, it can be estimated that the material contains approximately $3.1 \% \mathrm{Ru}$, thus finally confirming the catalyst composition as being 3.1\% $\mathrm{Ru} / \gamma-\mathrm{Al}_{2} \mathrm{O}_{3}$. Moreover, it was verified an increase in mass at $900{ }^{\circ} \mathrm{C}$, a characteristic phenomenon of carbon deposition formation.

The results of the Temperature Programmed Oxidation (TPO) after and before the TPR are shown in Fig. 8. Before the TPR, the material was not fully oxidized, where there was a mass increase from $150{ }^{\circ} \mathrm{C}$ to $300{ }^{\circ} \mathrm{C}$, approximately, and a further increase after $635^{\circ} \mathrm{C}$. After the TPR, the TPO showed a loss of mass from $150^{\circ} \mathrm{C}$ to $530^{\circ} \mathrm{C}$, which is characteristic of the oxidation of carbon deposits, but the production of $\mathrm{CO}$ or $\mathrm{CO}_{2}$ was not observed by mass spectrometry, probably due to the low deposit concentration on the catalyst surface. The increase in mass registered after $530^{\circ} \mathrm{C}$ is due to the catalyst reoxidation. 

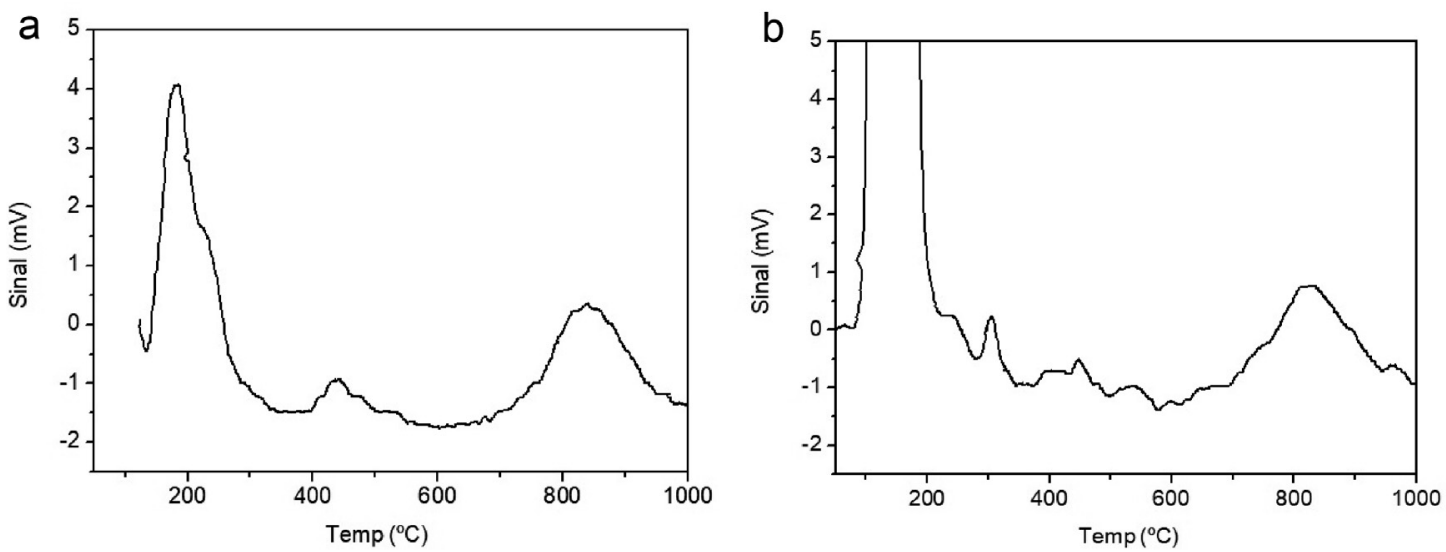

Fig. 6 - Ru catalyst (TPR) with $5 \% \mathrm{H}_{2} / \mathrm{N}_{2}$. a) Material after impregnation and drying at $120{ }^{\circ} \mathrm{C}$. b) Impregnated material, dried at $120{ }^{\circ} \mathrm{C}$, and subjected to reduction with hydrogen at $400^{\circ} \mathrm{C}$.

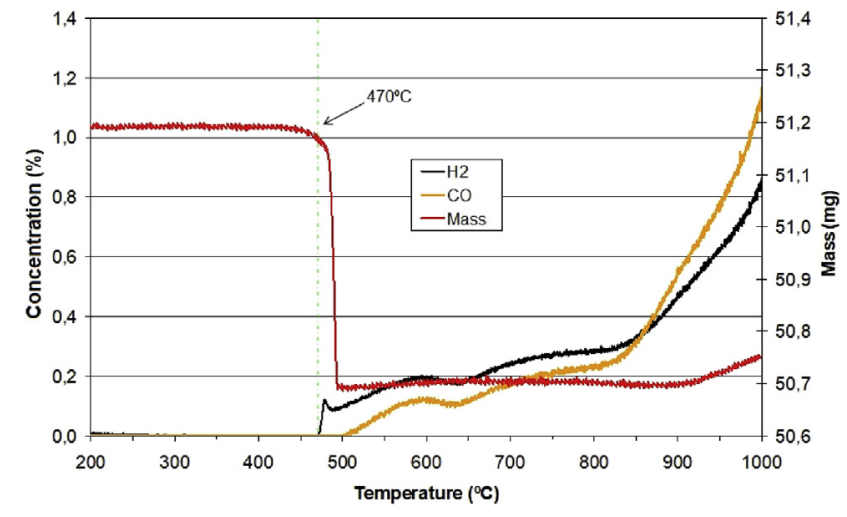

Fig. 7 - Ru catalyst (TPR) with $10 \% \mathrm{CH}_{4}$ and $10 \% \mathrm{CO}_{2}$.

\section{Catalytic test on biogas steam reforming reaction}

Reforming test with $7.4 \% \mathrm{Ni} / \mathrm{NiAl}_{2} \mathrm{O}_{4} / \gamma-\mathrm{Al}_{2} \mathrm{O}_{3}$ catalyst The reforming tests for the $\mathrm{Ni}$ catalyst were performed at three temperatures: $750{ }^{\circ} \mathrm{C}, 800{ }^{\circ} \mathrm{C}$, and $850{ }^{\circ} \mathrm{C}$ in an experimental steam reformer installation operating under atmospheric pressure. Two different compositions of biogas were investigated $\left(\mathrm{CH}_{4}: \mathrm{CO}_{2}=1.5: 1\right.$ and $\left.1: 1\right)$ with a constant steam/ biogas feed ratio of 1.5 and gas hourly space velocity (GHSV) of

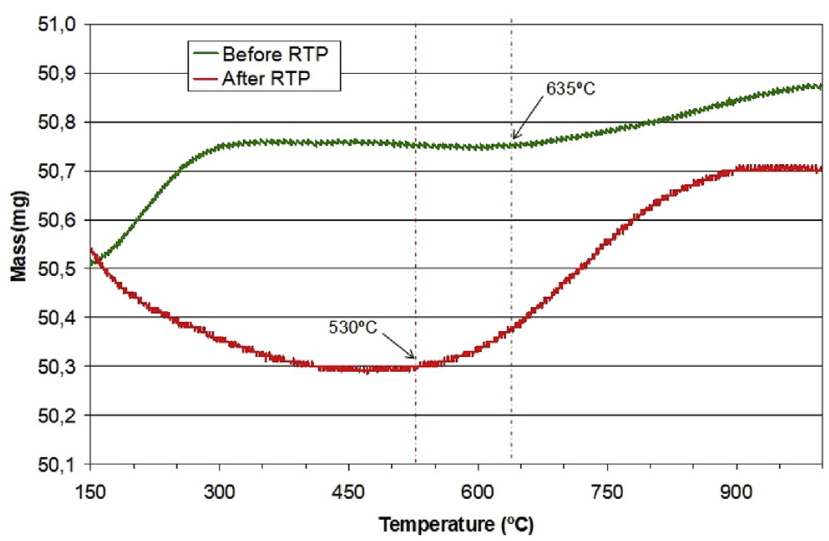

Fig. 8 - Mass curves during TPO of Ru catalyst with $20 \% \mathrm{O}_{2}$.
850 and $780 \mathrm{~h}^{-1}$, respectively. All experiments lasted $30 \mathrm{~min}$. The concentration curves were obtained from mass spectrometry and gas chromatography.

Fig. 9 shows the curves of the steam reforming of biogas (SRB) with a composition of $\mathrm{CH}_{4}: \mathrm{CO}_{2}=1.5: 1$ with the nickel catalyst, in which temperatures of $750{ }^{\circ} \mathrm{C}, 800{ }^{\circ} \mathrm{C}$, and $850{ }^{\circ} \mathrm{C}$, respectively, were kept for $30 \mathrm{~min}$. It was observed that, at temperatures ranging from $750{ }^{\circ} \mathrm{C}$ to $800{ }^{\circ} \mathrm{C}$, there was no methane consumption, therefore the steam reforming reaction could not occur. However, when the material was analyzed at $850^{\circ} \mathrm{C}$, a small peak of unreacted $\mathrm{CH}_{4}$ was found at the beginning of the experiment but, after a few minutes, the compound was completely consumed. During the experiment, it appears that the $\mathrm{H}_{2} / \mathrm{CO}$ ratio obtains a value of 2.9, which is very close to the one proposed in literature as optimal for $\mathrm{SRB}\left(\mathrm{H}_{2} / \mathrm{CO}=3\right)$ [4], thence evidencing high $\mathrm{CH}_{4}$ conversion.

Thus, it is possible to conclude that the steam reforming reaction was preponderant over the dry reforming reaction $\left(\mathrm{H}_{2} / \mathrm{CO}=1\right)$, which can be verified by the presence of large amounts of steam along the reaction. This behavior is different than the one reported by Sahi et al. [30] who had used a $\mathrm{NiO} / \gamma-\mathrm{Al}_{2} \mathrm{O}_{3}$ catalyst in which the increase of $\mathrm{H}_{2}$ production was mainly due to the large production of coal on account of the $\mathrm{CO}_{2}$ percentage being very low, therefore the WGS (water gas shift) reaction is not favored in such conditions. After $30 \mathrm{~min}$ of reform, the catalyst re-oxidation was accomplished, and it was found that there was no carbon deposition on the surface of the material, and that the release of $\mathrm{CO}_{2}$ or $\mathrm{CO}$ had been below detectable value. It was observed oxygen consumption during $0.35 \mathrm{~min}$, which is enough time for the catalyst reoxidation to occur. The average yield of $\mathrm{H}_{2}$ and $\mathrm{CO}$ products of syngas were $60 \%$ and $21 \%$, respectively, while $\mathrm{CH}_{4}$ was thoroughly consumed.

Fig. 10 shows the gas production curves that were obtained during the steam reforming of the second composition of biogas $\left(\mathrm{CH}_{4}: \mathrm{CO}_{2}=1: 1\right)$, which was kept at $850{ }^{\circ} \mathrm{C}$ for $30 \mathrm{~min}$, given that, in previous tests, the catalyst was not active at lower temperatures $\left(750-800{ }^{\circ} \mathrm{C}\right)$. The results indicated $\mathrm{a}_{2} /$ $\mathrm{CO}$ ratio of 2.3 during the reform. Note that methane was thoroughly consumed, i.e. an indicative of the reform 

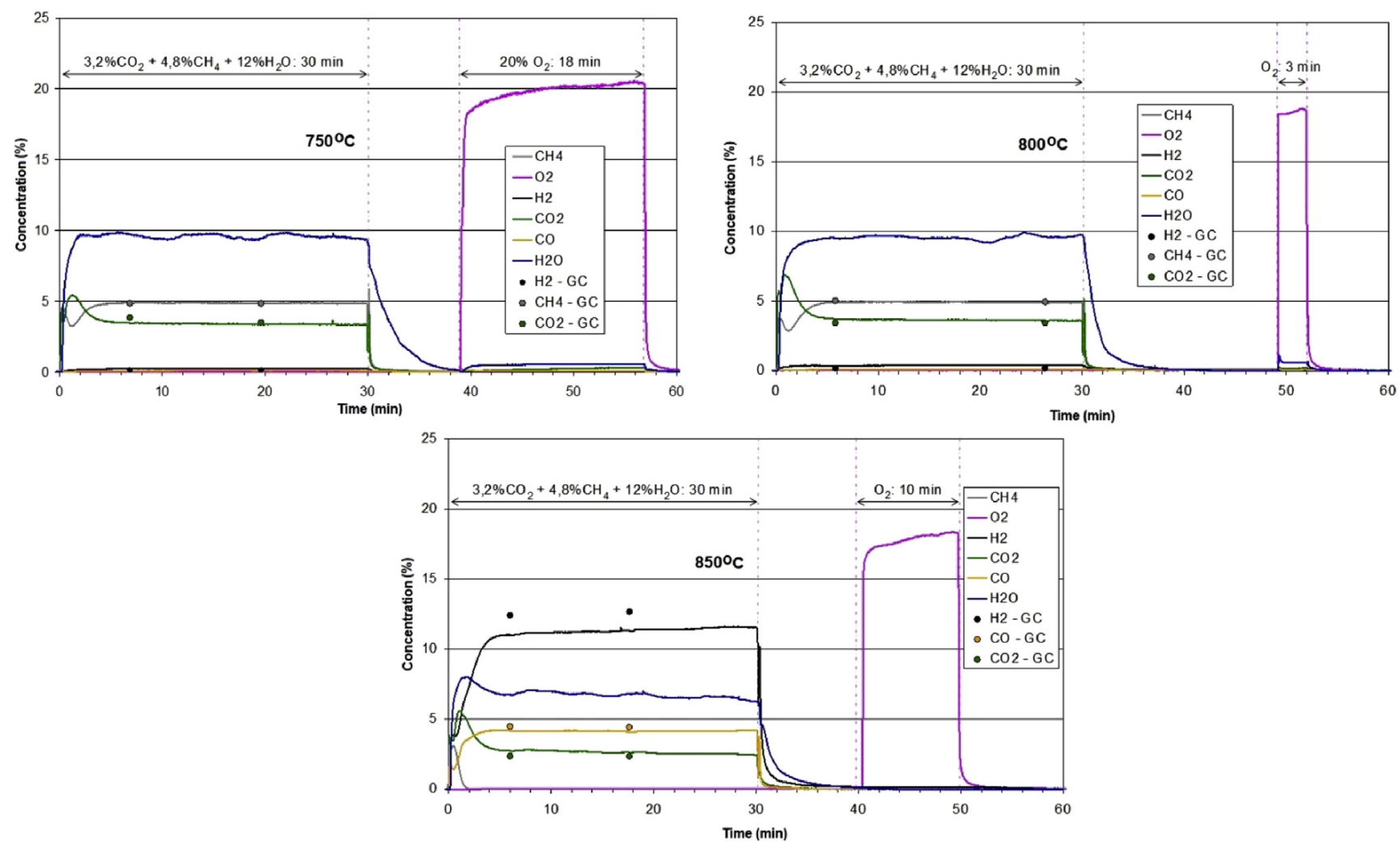

Fig. 9 - SRB with Ni catalyst $\left(\mathrm{CH}_{4}: \mathrm{CO}_{2}=1.5: 1\right.$; steam/biogas 1.5; pressure 1 bar; $\left.\mathrm{GHSV}=850 \mathrm{~h}^{-1}\right)$.

occurrence. As the $\mathrm{H}_{2} / \mathrm{CO}$ ratio is far from being ideal for a complete steam reforming occurrence, it can be affirmed that the biogas composition has a direct influence on whether the steam reforming process is predominant over the dry reforming process. It can be demonstrated by the $\mathrm{CO}_{2} / \mathrm{CO}$ ratio being approximately equal to 1 and a larger concentration of $\mathrm{CO}_{2}$ throughout the process (about 3.4\%) if compared to the previous test $(2.5 \%)$. As in the previous model $\left(\mathrm{CH}_{4}: \mathrm{CO}_{2}=1.5: 1\right)$, carbon deposition on the catalyst was not detected after catalyst re-oxidation.
From Figs. 9 and 10, a decrease in $\mathrm{CH}_{4}: \mathrm{CO}_{2}$ ratio afforded negligible effects on $\mathrm{CH}_{4}$ conversion at the selected temperature $\left(850{ }^{\circ} \mathrm{C}\right)$. In contrast, $\mathrm{H}_{2}$ yield and $\mathrm{H}_{2} / \mathrm{CO}$ ratio decreased from $60 \%$ to $45 \%$ and 2.9 to 2.3 , respectively, but $\mathrm{CO}_{2}$ concentration in the synthesis gas increases while the $\mathrm{CO}$ remained almost constant. This behavior may be the result of a higher $\mathrm{CO}_{2}$ concentration in the feed gas, which impairs the WGS reaction drive to decrease $\mathrm{CO}_{2}$ conversion, as well as the increase in the competition between dry reforming and steam reforming processes [42]. Nevertheless, steam reforming takes

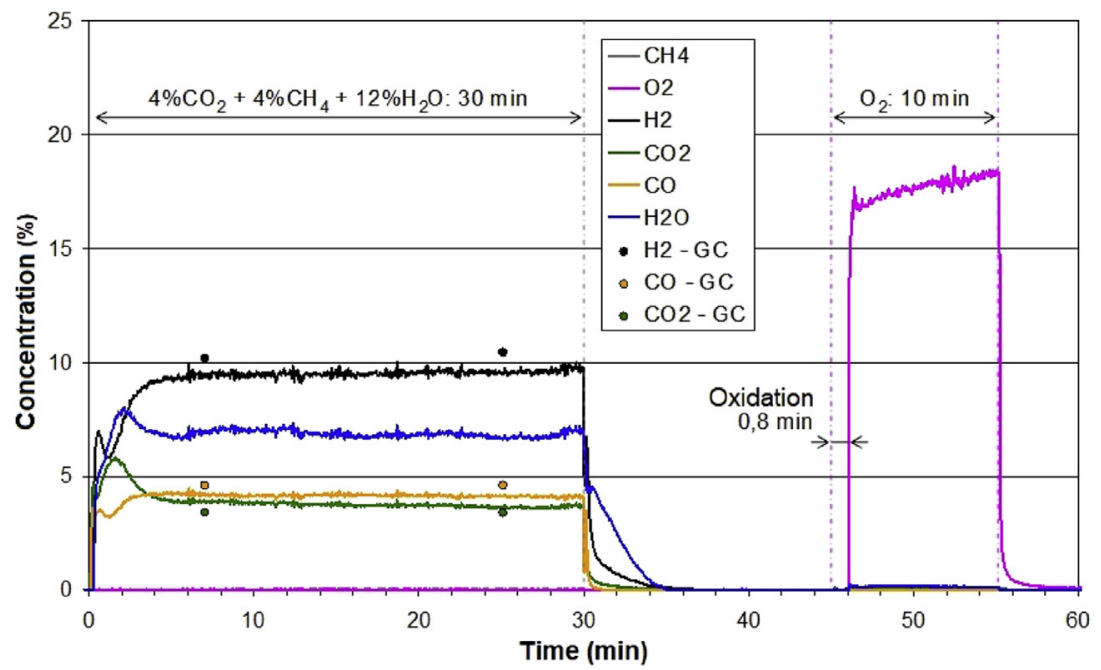

Fig. $10-\mathrm{SRB}$ with Ni catalyst $\left(\mathrm{CH}_{4}: \mathrm{CO}_{2}=1: 1\right.$; steam/biogas 1.5; pressure 1 bar; $\left.\mathrm{GHSV}=780 \mathrm{~h}^{-1}\right)$. 
place predominantly, since only $0.6 \%$ of $\mathrm{CO}_{2}$ reacted with methane in the dry reforming reaction.

When relatively long-term stability tests $(2 \mathrm{~h}$, not shown here) were performed for a biogas composition of $\mathrm{CH}_{4}: \mathrm{CO}_{2}=1: 1$, the $\mathrm{H}_{2} / \mathrm{CO}$ ratio was 2.4 and methane was completely consumed. This small increase in $\mathrm{H}_{2} / \mathrm{CO}$ ratio from the outset of the steam reforming process could be either linked to a catalytic dehydrogenation of $\mathrm{CH}_{4}$ or the WGS reactions [43]. These two reactions produce hydrogen, but dehydrogenation also produces carbon that might have been gasified by steam during the reforming process, given the fact that there was no production of $\mathrm{CO}$ or $\mathrm{CO}_{2}$ during the oxidation stage and no deactivation and coke deposition. Ni catalyst re-oxidation was performed in $1.8 \mathrm{~min}$, i.e. enough time to restore maximum oxygen content. On the other hand, biogas in the ratio of $\mathrm{CH}_{4}: \mathrm{CO}_{2}=1.5: 1.0$ behaved similarly in the longterm stability test in comparison with the one reported in Fig. 9.

Some studies about steam reforming processes using $\mathrm{Ni}$ catalysts have been reported, in which the steam reforming of biogas generally takes place over dry reforming processes $[11,22,24]$. However, there are few reports available in literature about the combination of both processes (steam and dry reforming process) [12]. Thus, its results from a combined use of steam reforming and dry reforming of methane are fundamental to find optimal operation process conditions, e.g. reactor temperature, in order to allow a viable process for producing synthesis gas from biogas without sintering or carbon deposition on the catalyst surface, which are the main problems faced in $\mathrm{Ni} / \gamma-\mathrm{Al}_{2} \mathrm{O}_{3}$ catalysts deactivation
[22]. The 7.4\% Ni/NiAl $\mathrm{O}_{4} / \gamma-\mathrm{Al}_{2} \mathrm{O}_{3}$ catalyst, which was evaluated experimentally, has showed relevant catalytic performances: high $\mathrm{CH}_{4}$ conversion, low carbon formation and $\mathrm{H}_{2}$ / $\mathrm{CO}$ ratio $\approx 3$. It can be assumed that $\mathrm{Ni}$ catalyst high performance and stability are mainly due to the formation of spinel $\mathrm{NiAl}_{2} \mathrm{O}_{4}$, thus causing high dispersion of very small nickel particles (being able to form $6 \mathrm{~nm}$ Ni crystallites) [17]. Moreover, the active phase distribution $\left(\mathrm{Ni}^{2+}\right)$ along particular sites that were formed after the spinel reduction is consistent with previous works reported by other researchers $[30,44,45]$.

On the other hand, its high resistance to coke deposition can be explained by the fact that the deposited carbon has a filamentous structure which allows the active metal to remain on the top of the carbon filament and, consequently, it remains accessible to reactants, thus resulting in a high and stable catalyst activity [24]. Another reason for such could be the high $\mathrm{H}_{2} / \mathrm{CO}$ ratios (more than 2) which can alleviate the carbon deposition problem. It is widely accepted that if $\mathrm{H}_{2} / \mathrm{CO}$ ratios are sufficiently high, the encapsulation of metal particles by the deposited carbon does not occur [45], therefore favoring catalytic activity. Presumably, this type of catalyst will be highly resistant to coking (over $100 \mathrm{~h}$ ), which is based on a previous study developed by Ref. [36], thus it is expected high durability.

Reforming test with 3.1\% $\mathrm{Ru} / \gamma-\mathrm{Al}_{2} \mathrm{O}_{3}$ catalyst The tests for the reforming of biogas with $\mathrm{CH}_{4}: \mathrm{CO}_{2}=1.5: 1$ with $\mathrm{Ru}$ catalyst were performed at temperatures of $650^{\circ} \mathrm{C}, 700^{\circ} \mathrm{C}$ and $7500^{\circ} \mathrm{C}$
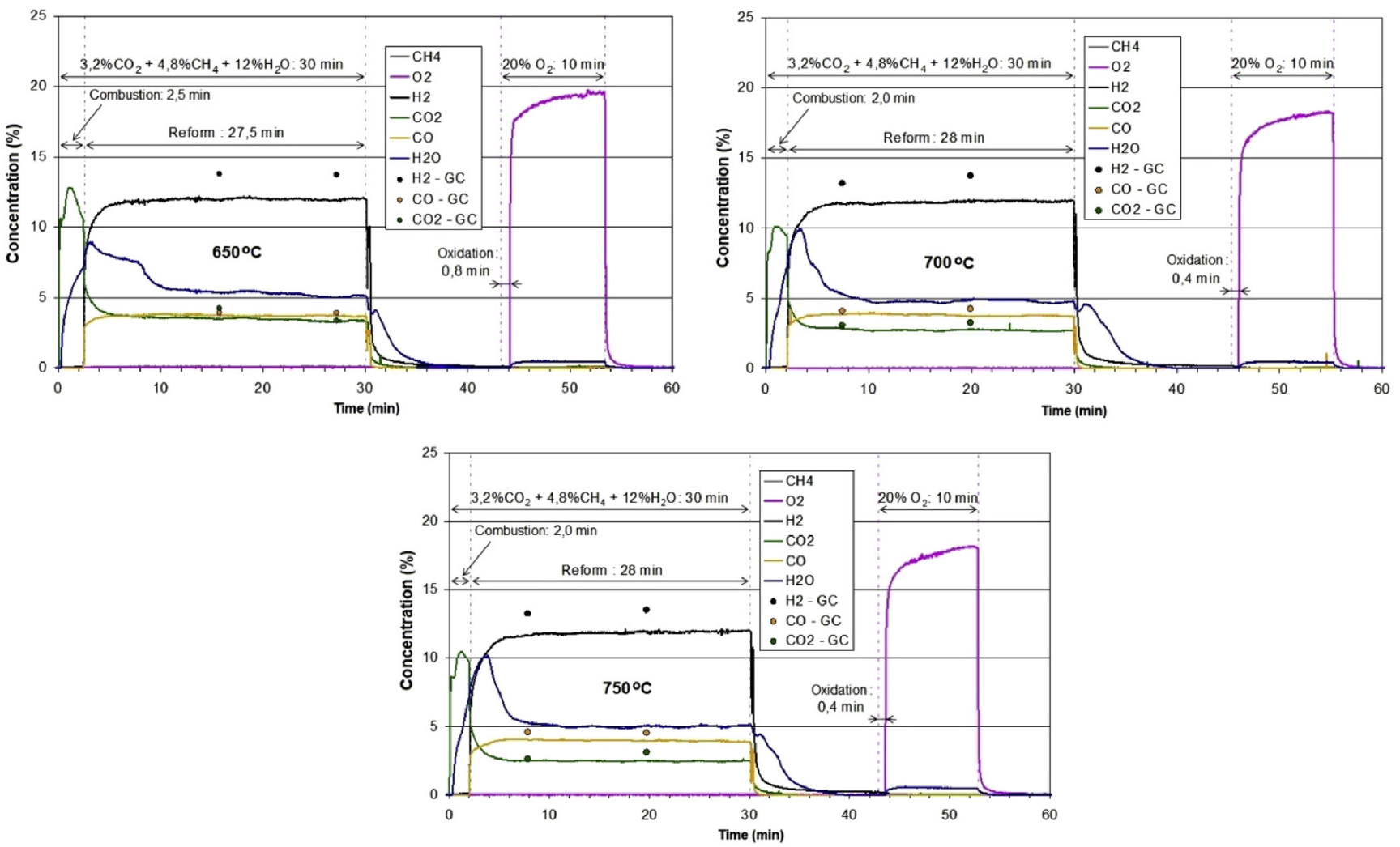

Fig. 11 - SRB with Ru catalyst $\left(\mathrm{CH}_{4}: \mathrm{CO}_{2}=1.5: 1\right.$; steam/biogas 1.5; pressure 1 bar; $\left.\mathrm{GHSV}=850 \mathrm{~h}^{-1}\right)$. 
Fig. 11 shows the concentration curves of syngas produced for the steam reforming with the ruthenium catalyst kept during $30 \mathrm{~min}$. It is possible to observe that an increase in temperature from 650 to 750 does not lead to a significant increase in $\mathrm{H}_{2}$ or $\mathrm{CO}$ production, in accordance with [17], as it is well known that in order to increase the quantity of produced hydrogen, high temperatures are needed. For the reforming process carried out at $650{ }^{\circ} \mathrm{C}$, the results were 2.5 min of combustion; $0.14 \%$ of unconsumed methane and an $\mathrm{H}_{2} / \mathrm{CO}$ ratio of 3.5. This value indicates that the formation of $\mathrm{H}_{2}$ occurred through the steam reforming preponderantly and by simultaneous reactions, like methane decomposition and WGS reaction. These two reactions produce hydrogen, while dehydrogenation produces carbon that might have been gasified by steam during the reforming reaction, given the fact that there was no $\mathrm{CO}_{2}$ or $\mathrm{CO}$ production during oxidation. The concentration ratio of $\mathrm{CO}_{2} / \mathrm{CO}$ was approximately 1 , which allows assuming that the steam reforming, WGS and carbon gasification (disproportionation reaction) reactions occurred simultaneously at the same rate [17].

From Fig. 11, it is also possible to observe an increase in CO concentration and a decrease in $\mathrm{H}_{2} / \mathrm{CO}$ ratio ( 3.0) with increased temperature $\left(700-750{ }^{\circ} \mathrm{C}\right)$, which is consistent with the fact that the WGS reaction is less favorable thermodynamically at higher temperatures $[27,42]$. These results suggested that as $\mathrm{CO}$ yield increases, $\mathrm{H}_{2}$ remained almost constant, while $\mathrm{CO}_{2}$ yield decreased at relatively high temperatures [46]. It can be explained by the increased contributions of dry reforming of methane and reverse water gas shift (RWGS) reaction to produce $\mathrm{CO}$ in the steam biogas reforming reaction [47], which implies that the $\mathrm{CO}_{2}$ production rate via the WGS reaction is comparable to the dry reforming of $\mathrm{CH}_{4}$ at $750{ }^{\circ} \mathrm{C}$ [42]. However, the steam reforming reaction is still predominant over the dry reforming reaction because the $\mathrm{H}_{2}$ / CO ratio was about 3.0, which is ideal for SRB [4]. Generally, $\mathrm{CH}_{4}$ conversions increase as temperature does for all tested ranges, as found by Ref. [17]. The amount of unconsumed methane were $0.05 \%$ at $700{ }^{\circ} \mathrm{C}$ and $0.04 \%$ at $750{ }^{\circ} \mathrm{C}$, respectively, i.e. much lower values than those reported at $650{ }^{\circ} \mathrm{C}$.

The influence of $\mathrm{CH}_{4}: \mathrm{CO}_{2}$ ratio on inlet gas feed was also examined. Fig. 12 shows the catalyst behavior for a long- term stability test (two hours) with $\mathrm{CH}_{4}: \mathrm{CO}_{2}$ ratio of $1: 1$ at $700{ }^{\circ} \mathrm{C}$. When the inlet gas ratio decreases, it can be observed that $\mathrm{H}_{2}$ yield decreased from $60 \%$ at an inlet gas ratio of $1.5: 1-47.5 \%$ at a ratio of $1: 1$ by keeping the same catalyst temperature, which also leads to a decrease at a $\mathrm{H}_{2} / \mathrm{CO}$ ratio of around $17 \%$. These facts are consistent with previous studies reported by Refs. [27,48]. In contrast, $\mathrm{CO}_{2}$ concentration increased significantly as the $\mathrm{CH}_{4}: \mathrm{CO}_{2}$ ratio decreased from $15 \%$ to $25 \%$. This increase in $\mathrm{CO}_{2}$ concentration brings about negligible effects on $\mathrm{CH}_{4}$ conversion, thus maintaining the unconsumed methane at $0.04 \%$. The aforementioned could be explained by a decrease in $\mathrm{CO}_{2}$ conversion, thus indicating that a greater quantity of $\mathrm{CO}_{2}$ is produced as a result of the combination of methane steam reforming and WGS reactions, which is greater than that consumed by the dry reforming and the RWGS reactions [48]. Furthermore, the results of the long-term stability test clearly indicate that, after two hours of reaction, both the conversion and selectivity tend to behave similarly, which is fairly stable along the reaction, in which deactivation or carbon deposition on the catalyst surface is not observed. It is expected high activity and good stability in the long-term for this type of catalyst, since these are the main advantages of catalysts based on noble metals, such as $\mathrm{Ru}$, with high resistance to carbon deposition [48].

\section{Comparison of nickel and ruthenium catalysts from the performance evaluation}

It was performed an evaluation of two catalytic materials in the biogas steam reforming reaction. Catalysts containing about $7.4 \%$ of $\mathrm{Ni}\left(7.4 \% \mathrm{Ni} / \mathrm{NiAl}_{2} \mathrm{O}_{4} / \gamma-\mathrm{Al}_{2} \mathrm{O}_{3}\right)$ and $3.1 \%$ of ruthenium $\left(3.1 \% \mathrm{Ru} / \gamma-\mathrm{Al}_{2} \mathrm{O}_{3}\right.$ ) supported on a gamma alumina were analyzed. The materials were characterized by the reduction reaction with hydrogen with a chemisorption equipment, followed by oxidation in a thermo balance attached to a mass spectrometer. In Table 3, the main comparative results are listed.

In comparison with the $\mathrm{Ni} / \mathrm{NiAl}_{2} \mathrm{O}_{4} / \gamma-\mathrm{Al}_{2} \mathrm{O}_{3}$ catalyst, the analysis showed a lower temperature reduction for ruthenium. At this point, $\mathrm{Ru} / \gamma-\mathrm{Al}_{2} \mathrm{O}_{3}$ has an advantage, since $\mathrm{CO}$

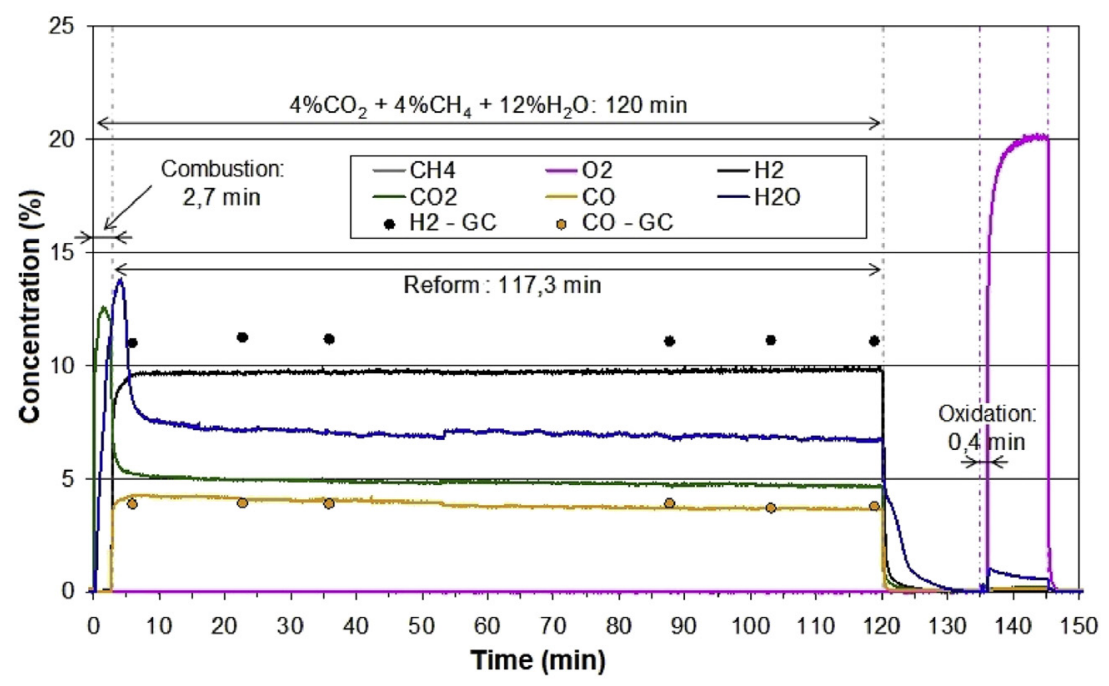

Fig. 12 - SRB with Ru catalyst $\left(\mathrm{CH}_{4}: \mathrm{CO}_{2}=1: 1\right.$; steam/biogas 1.5; pressure 1 bar; $\left.\mathrm{GHSV}=780 \mathrm{~h}^{-1}\right)$. 
Table 3 - Comparison of Nickel and Ruthenium catalysts from the performance evaluation.

\begin{tabular}{lcc} 
& $7.4 \% \mathrm{Ni} / \mathrm{NiAl}_{2} \mathrm{O}_{4} / \gamma-\mathrm{Al}_{2} \mathrm{O}_{3}$ & $3.1 \% \mathrm{Ru} / \gamma-\mathrm{Al}_{2} \mathrm{O}_{3}$ \\
\hline Reduction temperature & $800{ }^{\circ} \mathrm{C}$ & $470{ }^{\circ} \mathrm{C}$ \\
Temperature for efficient reforming reactions & $850{ }^{\circ} \mathrm{C}$ & $700^{\circ} \mathrm{C}$ \\
Carbon deposition or catalyst deactivation & None & None \\
$\mathrm{H}_{2}$ CO ratio for biogas composition $\left(\mathrm{CH}_{4}: \mathrm{CO}_{2}=1.5: 1 / \mathrm{CH}_{4}: \mathrm{CO}_{2}=1: 1\right)$ & $2.9 / 2.4$ & $3 / 2.4$ \\
$\mathrm{H}_{2}$ yield & $60 \%$ & $60 \%$ \\
\hline
\end{tabular}

and $\mathrm{H}_{2}$ are produced (characteristic of dry reforming) from $470{ }^{\circ} \mathrm{C}$, i.e. a temperature that is much lower than that obtained with the Ni catalyst $\left(800^{\circ} \mathrm{C}\right)$.

The $\mathrm{Ni}$ catalyst proved efficient in reforming reactions whose temperature is equal to or greater than $850^{\circ} \mathrm{C}$. At lower temperatures, the catalyst was not enough for activating the reforming reaction. As the amount of $\mathrm{CO}_{2}$ increased in the biogas composition $\left(\mathrm{CH}_{4}: \mathrm{CO}_{2}=1.5: 1\right.$ to $\left.\mathrm{CH}_{4}: \mathrm{CO}_{2}=1: 1\right)$, there was a decrease in $\mathrm{H}_{2}$ /CO ratio from 2.9 to 2.4 by an increase in the dry reforming rate when the nickel catalyst was used. During the experiments, no carbon deposition or catalyst deactivation was noted.

On the other hand, the reactions with the Ru catalyst presented an $\mathrm{H}_{2} / \mathrm{CO}$ ratio which is closer to the value found in literature for the steam reforming $\left(\mathrm{H}_{2} / \mathrm{CO}=3\right)$, thus indicating that this material is efficient and selective for this reaction. In addition, the working temperature is much lower than the one used with the Ni catalyst. There was no deactivation, nor a significant formation of carbon deposition in any of the experiments, which suggests great durability of these catalysts without the need for frequent regenerations.

When comparing the performance of the Ni catalyst in Fig. 9 working at $850^{\circ} \mathrm{C}$ to the Ru catalyst shown in Fig. 11 at $700{ }^{\circ} \mathrm{C}, \mathrm{H}_{2}$ yield was very similar $(\sim 60 \%)$ and $\mathrm{H}_{2} / \mathrm{CO}$ ratio was 2.9 and 3, respectively, thus showing that both catalysts have a similar behavior when they are used in the steam reforming of biogas. The same conclusion is reached when comparing the performance of catalysts in the long-term stability test by using a ratio of $\mathrm{CH}_{4}: \mathrm{CO}_{2}=1: 1$. From Figs. 10 and 12, it can be observed that the concentrations of gases it produced are almost the same as the $\mathrm{H}_{2}$ yield of $47.5 \%$ and a $\mathrm{H}_{2} / \mathrm{CO}$ ratio of 2.4. The main difference between both catalysts was in the yield of $\mathrm{CO}_{2}$ production, being of $19.5 \%$ for Ni catalyst and $25 \%$ for Ru catalyst.

It is known that the use of noble metals such as Rh, Pd, Ir, Pt and $\mathrm{Ru}$ lead to an improvement in catalyst activity, thus making it more stable and attenuating coke formation [47] in comparison with the $\mathrm{Ni}$ catalyst which has the limitation of coke deposition and deactivation susceptibility at higher temperatures $[17,22]$. However, a nickel catalyst with an interfacial nickel aluminate layer $\left(\mathrm{NiAl}_{2} \mathrm{O}_{4}\right)$ allows a prominent performance with high activity $[30,36]$. On the other hand, the use of noble metals in catalysts is limited to experimental tests in laboratory, not being developed commercially for economic reasons [3]. Therefore, by considering the results achieved in this study, the $7.4 \% \mathrm{Ni} / \mathrm{NiAl}_{2} \mathrm{O}_{4} / \gamma-\mathrm{Al}_{2} \mathrm{O}_{3}$ catalyst is proved suitable for the steam reforming of biogas, which it is less expensive than the $\mathrm{Ru}$ catalyst with almost the same performance. Furthermore, this type of catalyst has a great potential for industrial application in the future [27].

\section{Conclusion}

Steam reforming of biogas has been studied with two types of catalysts: nickel 7.4\% Ni/ $\mathrm{NiAl}_{2} \mathrm{O}_{4} / \gamma-\mathrm{Al}_{2} \mathrm{O}_{3}$ and Ruthenium 3.1\% $\mathrm{Ru} / \gamma-\mathrm{Al}_{2} \mathrm{O}_{3}$. The following conclusions can be drawn:

1) The Ni catalyst proved efficient in reforming reactions whose temperature is equal to or higher than $850{ }^{\circ} \mathrm{C}$. At lower temperatures, the catalyst was not enough for the steam reforming reaction activation.

2) Both catalysts showed the same behavior with an increase in $\mathrm{CO}_{2}$ concentration in the gas feed, which leads to decrease in $\mathrm{H}_{2}$ /CO ratio and $\mathrm{H}_{2}$ yield, thus showing that optimal performance is achieved at a $\mathrm{CH}_{4}: \mathrm{CO}_{2}$ ratio of 1.5:1.

3) Further investigation on carbon deposition was conducted by characterizing the catalysts used in the steam reforming of biogas. Both catalysts showed no deactivation during these tests and the amount of carbon formed was at very low levels, and there was no production of $\mathrm{CO}$ or $\mathrm{CO}_{2}$, which could be found by mass spectrometry, thus indicating that these materials are efficient and selective for the steam reforming of biogas with high resistance to coke formation.

4) An excellent reactivity of $7.4 \% \mathrm{Ni} / \mathrm{NiAl}_{2} \mathrm{O}_{4} / \gamma-\mathrm{Al}_{2} \mathrm{O}_{3}$ catalyst is a result of the existence of an interfacial $\mathrm{NiAl}_{2} \mathrm{O}_{4}$ layer that stabilizes the formation of low size nickel particles, and the high dispersion and distribution of the active phase on the support effectively suppress catalyst sintering, thus leading to practically the same performance as the Ru catalyst.

\section{Acknowledgements}

This work was financed by FAPESP (São Paulo State Research Foundation, process number 06/52260-2). The authors are also grateful to the Coordination for the Improvement of Higher Education Personnel (CAPES), from the Brazilian Ministry of Education (MEC). The authors would also like to acknowledge the language revision services provided by FAV Language Services.

\section{R E F E R E N C E S}

[1] Bollini L, Silveira JL, Evaristo M, Tuna CE, Machin EB, Pedroso DT. Hydrogen production by biogas steam reforming: a technical, economic and ecological analysis. Renew Sustain Energy Rev 2013;28:166-73. 
[2] Xu J, Zhou W, Li Z, Wang J, Ma J. Biogas reforming for hydrogen production over a Ni-Co bimetallic catalyst: effect of operating conditions. Int J Hydrogen Energy 2010;35:13013-20.

[3] Therdthianwong S, Siangchin C, Therdthianwong A. Improvement of coke resistance of $\mathrm{Ni} / \mathrm{Al}_{2} \mathrm{O}_{3}$ catalyst in $\mathrm{CH}_{4} /$ $\mathrm{CO}_{2}$ reforming by $\mathrm{ZrO}_{2}$ addition. Fuel Process Technol 2007;9:0-8.

[4] Rick R, Pires E, Jose H, Sato M, Coimbra-arau CH. Overview of hydrogen production technologies from biogas and the applications in fuel cells. Int J Hydrogen Energy 2013;38:5215-25.

[5] ENERGY USD-EEAR. Hydrogen, fuel cells \& infrastructure technologies program. 2005. http://www1.eere.energy.gov/ hydrogenandfuelcells/mypp/.

[6] Steinberg M. The Hy-C process (thermal decomposition of natural gas) potentially the lowest cost source of hydrogen with the least $\mathrm{CO}_{2}$ emission. Energy Convers Manag 1995;36:791-6.

[7] Poirier MG, Sapundzhiev C. Catalytic decomposition of natural gas to hydrogen for fuel cell applications. Int J Hydrogen Energy 1997;22:429-33.

[8] Effendi A, Hellgardt $\mathrm{K}$, Zhang Z, Yoshida T. Optimising $\mathrm{H}_{2}$ production from model biogas via combined steam reforming and CO shift reactions. Fuel 2005;84:869-74.

[9] Formanski V, Kalk T, Roes J. Compact hydrogen production systems for solid polymer fuel cells. J Power Sources 1998;71:199-207.

[10] Villacampa JI, Royo C, Romeo E, Montoya JA, Del Angel P, Monzón A. Catalytic decomposition of methane over Ni$\mathrm{Al}_{2} \mathrm{O}_{3}$ coprecipitated catalysts: reaction and regeneration studies. Appl Catal A Gen 2003;252:363-83.

[11] Benito M, Garc S, Garc L, Daza L. Development of biogas reforming Ni-La-Al catalysts for fuel cells. J Power Sources 2007;169:177-83.

[12] Kolbitsch P, Pfeifer C, Hofbauer H. Catalytic steam reforming of model biogas. Fuel 2008;87:701-6.

[13] Barrai F, Jackson T, Whitmore N, Castaldi MJ. The role of carbon deposition on precious metal catalyst activity during dry reforming of biogas. Catal Today 2007;129:391-6.

[14] Shuyan W, Lijie Y, Huilin L, Yurong H. Simulation of effect of catalytic particle clustering on methane steam reforming in a circulating fluidized bed reformer. Chem Eng J 2008;139:136-46.

[15] Ma Y, Xu Y, Demura M, Hirano T. Catalytic stability of $\mathrm{Ni}_{3} \mathrm{Al}$ powder for methane steam reforming. Appl Catal B Environ 2008;80:15-23.

[16] Sun H, Wang H, Zhang J. Preparation and characterization of nickel - titanium composite xerogel catalyst for $\mathrm{CO}_{2}$ reforming of $\mathrm{CH}_{4}$. Appl Catal B Environ 2007;73:158-65.

[17] Goula MA, Charisiou ND, Papageridis KN, Delimitis A, Pachatouridou E, Iliopoulou EF. Nickel on alumina catalysts for the production of hydrogen rich mixtures via the biogas dry reforming reaction: influence of the synthesis method. Int J Hydrogen Energy 2015;40:9183-200.

[18] Urasaki K, Sekine Y, Kawabe S, Kikuchi E, Matsukata M. Catalytic activities and coking resistance of $\mathrm{Ni} /$ perovskites in steam reforming of methane. Appl Catal A Gen 2005;286:23-9.

[19] Fonseca A, Assaf EM. Production of the hydrogen by methane steam reforming over nickel catalysts prepared from hydrotalcite precursors. J Power Sources 2005;142:154-9.

[20] Sabirova ZA, Danilova MM, Zaikovskii VI, Kuzin NA, Kirillov VA, Kriger TA, et al. Nickel catalysts based on porous nickel. Kinet Catal 2010;49:428-34.

[21] Taylor K, Mason D, Lo DG. A light hydrocarbon fuel processor producing high-purity hydrogen. J Power Sources 2003;117:84-91.
[22] Xu J, Zhou W, Li Z, Wang J, Ma J. Biogas reforming for hydrogen production over nickel and cobalt bimetallic catalysts. Int J Hydrogen Energy 2009;34:6646-54.

[23] Angeli SD, Pilitsis FG, Lemonidou AA. Methane steam reforming at low temperature: effect of light alkanes' presence on coke formation. Catal Today 2015;242:119-28.

[24] Luna AEC, Iriarte ME. General Carbon dioxide reforming of methane over a metal modified $\mathrm{Ni}-\mathrm{Al}_{2} \mathrm{O}_{3}$ catalyst. Appl Catal A Gen 2008;343:10-5.

[25] Zhang ZL, Tsipouriari VA, Efstathiou AM, Verykios XE. Reforming of methane with carbon dioxide to synthesis gas over supported rhodium catalysts: I. Effects of support and metal crystallite size on reaction activity and deactivation characteristics. J Catal 1996;158:51-63.

[26] Therdthianwong S, Summaprasit N. Synthesis gas production from $\mathrm{CH}_{4}$ reforming with $\mathrm{CO}_{2}$ over $\mathrm{Pd} / \mathrm{Al}_{2} \mathrm{O}_{3}$ promoted with $\mathrm{CeO}_{2}$. Asian J Energy Environ 2002;3:1-25.

[27] Avraam DG, Halkides TI, Liguras DK, Bereketidou OA, Goula MA. An experimental and theoretical approach for the biogas steam reforming reaction. Int J Hydrogen Energy 2010;5:1-10.

[28] Zhang ZG, Xu G, Chen X, Honda K, Yoshida T. Process development of hydrogenous gas production for PEFC from biogas. Fuel Process Technol 2004;85:1213-29.

[29] Lucrédio AF, Assaf JM, Assaf EM. Reforming of a model biogas on Ni and Rh-Ni catalysts: effect of adding La. Fuel Process Technol 2012;102:124-31.

[30] Salhi N, Boulahouache A, Petit C, Kiennemann A, Rabia C. Steam reforming of methane to syngas over $\mathrm{NiAl}_{2} \mathrm{O}_{4}$ spinel catalysts. Int J Hydrogen Energy 2010;6:3-9.

[31] El Doukkali M, Iriondo A, Arias PL, Requies J, Gandarías I, Jalowiecki-Duhamel L, et al. A comparison of sol-gel and impregnated Pt or/and Ni based $\gamma$-alumina catalysts for bioglycerol aqueous phase reforming. Appl Catal B Environ 2012;125:516-29.

[32] Al-Ubaid A, Wolf EE. Steam reforming of methane on reduced non-stoichiometric nickel aluminate catalysts. Appl Catal 1988;40:73-85.

[33] Lif J, Skoglundh M, Löwendahl L. Sintering of nickel particles supported on $\gamma$-alumina in ammonia. Appl Catal A Gen 2002;228:145-54.

[34] Zielinski J. Morphology of nickel/alumina. J Catal 1982;76:157-63.

[35] Zhang LF, Lin JF, Yi C. Characterization of dispersion and surface states of $\mathrm{NiO} / \mathrm{g}$-alumina and $\mathrm{NiO} / \mathrm{La}_{2} \mathrm{O}_{3}$-g-alumina catalysts. J Chem Soc Faraday Trans 1992;88(3):497-502.

[36] Zhou L, Guo Y, Zhang Q, Yagi M, Hatakeyama J, Li H, et al. A novel catalyst with plate-type anodic alumina supports $\mathrm{Ni} /$ $\mathrm{NiAl}_{2} \mathrm{O}_{4} / \mathrm{g}-\mathrm{Al}_{2} \mathrm{O}_{3} /$ alloy, for steam reforming of methane. Appl Catal A Gen 2008;347:200-7.

[37] Betancourt P, Rives A, Hubaut R, Scott CE, Goldwasser J. A study of the ruthenium-alumina system. Appl Catal A Gen 1998:170.

[38] Koopman PGJ, Kieboom APG, Van Bekkum H. Characterization of ruthenium catalysts as studied by temperature programmed reduction. J Catal 1981;69:172-9.

[39] Mazzieri V, Coloma-Pascual F, Arcoya A, L'Argentière PC, Fígoli NS. XPS, FTIR and TPR characterization of $\mathrm{Ru} / \mathrm{Al}_{2} \mathrm{O}_{3}$ catalysts. Appl Surf Sci 2003;210:222-30.

[40] Safariamin M, Tidahy LH, Abi-Aad E, Siffert S, Aboukails A. Dry reforming of methane in the presence of ruthenium-based catalysts. Comptes Rendus Chim 2009;12:748-53.

[41] Gil A, Diaz A, Gandia LM, Mantes M. Influence of the preparation method and the nature of the support on the stability of nickel catalysts. Appl Catal A Gen 1994;109:167-79. 
[42] Thi Q, Bui P, Kim Y, Pil S, Han J, Chul H, et al. Steam reforming of simulated biogas over plate $\mathrm{Ni} C r$ catalysts: influence of pre-oxidation on catalytic activity. Appl Catal B Environ 2015;167:335-44.

[43] Khoshtinat Nikoo M, Amin NAS. Thermodynamic analysis of carbon dioxide reforming of methane in view of solid carbon formation. Fuel Process Technol 2011;92:678-91.

[44] Jiménez-González C, Boukha Z, de Rivas B, Delgado JJ, Cauqui MA, González-Velasco JR, et al. Structural characterisation of Ni/alumina reforming catalysts activated at high temperatures. Appl Catal A Gen 2013;466:9-20.

[45] Boukha Z, Jiménez-González C, de Rivas B, GonzálezVelasco JR, Gutiérrez-Ortiz JI, López-Fonseca R. Synthesis, characterisation and performance evaluation of spinelderived $\mathrm{Ni} / \mathrm{Al}_{2} \mathrm{O}$ catalysts for various methane reforming reactions. Appl Catal B Environ 2014;158-159:190-201.

[46] Chang AC, Lee K. Biogas reforming by the honeycomb reactor for hydrogen production. Int J Hydrogen Energy 2015:1-8.

[47] Roy PS, Park CS, Raju ASK, Kim K. Steam-biogas reforming over a metal-foam-coated ( $\mathrm{Pd}-\mathrm{Rh}) /\left(\mathrm{CeZrO}_{2}-\mathrm{Al}_{2} \mathrm{O}_{3}\right)$ catalyst compared with pellet type alumina-supported $\mathrm{Ru}$ and $\mathrm{Ni}$ catalysts. J CO2 Util 2015;12:12-20.

[48] Ahmed S, Lee SHD, Ferrandon MS. Catalytic steam reforming of biogas-Effects of feed composition and operating conditions. Int J Hydrogen Energy 2015;40:105-15. 